\title{
MORPHOLOGICAL AND GENETIC VARIATION IN CICINDELA LUSITANICA MANDL, 1935 (COLEOPTERA, CARABIDAE, CICINDELINAE): IMPLICATIONS FOR CONSERVATION
}

\author{
A. Cardoso ${ }^{1,2 *}$, A. P. Vogler ${ }^{1,3}$ and A. Serrano ${ }^{2}$
}

\begin{abstract}
The establishment of taxonomic and geographical boundaries is a common problem when analysing clinal distributions. This is of particular concern when the assessment of intraspecific groupings is required for conservation management. The tiger beetle Cicindela lusitanica Mandl, 1935 (Coleoptera, Carabidae) is a typical case in which two recognised subspecies are distributed in a clinal latitudinal fashion in the dune systems along the Atlantic coast of Portugal. This habitat is increasingly under threat, and conservation measures are needed. We investigated the validity of the two named subspecies, based on a re-analysis of elytral and genitalic measurements using multivariate analysis. We also analysed variation in mitochondrial Cytochrome Oxidase I gene for a total of six populations along the cline. Multivariate analysis supported the idea of a morphological cline and revealed a clear distinction of the southernmost population and also some degree of distinctiveness of the most northern populations, partially supporting the recognised subspecific ranking. The mtDNA analysis identified two main groups corresponding to northern and southern populations. Both sets of markers showed that variation within the $C$. lusitanica assemblage is complex, with the boundaries between morphological and mtDNA groups not in agreement. However, populations at either end of the distributional range are clearly distinct from each other, and should be considered as provisional units for conservation programmes.
\end{abstract}

Key words: Coleoptera, Carabidae, Cicindela, cline, mtDNA, elytral colouration, morphometric analysis, population aggregation analysis, conservation.

\section{RESUMEN}

Variación morfológica y genética en Cicindela lusitanica (Coleoptera, Carabidae, Cicindelinae): implicaciones para su conservación

El reconocimiento de límites taxonómicos y geográficos de la variabilidad observada es un problema habitual cuando se analizan distribuciones clinales. Esto es particularmente problemático cuando se requiere la determinación de agrupamientos intraespecíficos para tomar medidas de conservación. El cicindélido Cicindela lusitanica Mandl, 1935 (Coleoptera, Carabidae) constituye un caso típico en el que dos subespecies reconocidas se hayan distribuidas a lo largo de una clina latitudinal en los sistemas dunares de la costa Atlántica Portuguesa. Este hábitat se encuentra cada vez más amenazado y se requiere tomar medidas de conservación. En este trabajo hemos investigado la validez de las dos subespecies propuestas basándonos en un reanálisis de medidas elitrales y de la genitalia usando análisis multivariante. También hemos estudiado la variación en el gen de la Citocromo Oxidasa I para un total de seis poblaciones a lo largo de la clina. El análisis multivarian-

The Natural History Museum, Department of Entomology, Cromwell Road, London SW7 5BD, United Kingdom.

Faculdade de Ciências da Universidade de Lisboa, Departamento de Biologia Animal/ Centro de Biologia Ambiental, Rua Ernesto Vasconcelos, 1749-016, Campo Grande, Lisboa, Portugal. Telephone: +351 217500000 extension 22325, Email: adcardoso@fc.ul.pt

Department of Biological Sciences, Imperial College London, Silwood Park Campus, Ascot SL5 7PY, United Kingdom.

* Corresponding Author 
te confirmó la idea de la existencia de una clina morfológica y reveló una clara distinción de la población más meridional y también una cierta distinción de las poblaciones más septentrionales, apoyando parcialmente los rangos subespecíficos reconocidos. El análisis del ADN mitocondrial identificó dos grupos principales correspondientes a las poblaciones del norte y las del sur. Ambos conjuntos de marcadores evidenciaron que la variación en $C$. lusitanica es compleja, con límites discordantes entre los grupos definidos por la morfología y por el ADN mitocondrial. Sin embargo, las poblaciones en los extremos del área de distribución son claramente distintas entre sí, y deberían ser consideradas unidades provisionales en programas de conservación.

Palabras clave: Coleoptera, Carabidae, Cicindela, clina, ADN mitocondrial, coloración elitral, análisis morfométrico, análisis de agregación poblacional, conservación.

\section{Introduction}

Species distributed along climatic gradients frequently exhibit morphological variation in a clinal fashion. Such variation may cause difficulties for taxonomy, as no clear morphological entities can be delineated. Frequently, taxonomists have attempted to section the clines into distinct subspecies, but this may be artificial. In addition, such subspecific assignments may be of little taxonomic value and do not reflect species history because the morphological characters chosen are under environmental selection. In endangered species, anthropogenic habitat fragmentation may break up continuous distributions along those clines, altering population structure and gene flow patterns and hence contributing to population decline and extirpation. Therefore, the difficulties to define taxonomic boundaries along clines constitute also a problem for conservation, due to the need for delineating distinct entities for management.

Cicindela lusitanica Mandl, 1935 (Coleoptera, Carabidae) is represented by a morphological cline along the secondary dune systems of the Portuguese Atlantic coastline (Serrano, 1988). This species belongs to the $C$. hybrida complex, the most widespread Palearctic species group in the genus Cicindela (s. str.) (Gebert, 1995, 1999). The C. hybrida group is known for its complex taxonomy evident at regional and local levels. Within this group, $C$. lusitanica is taxonomically well established, as it is clearly distinct from other named taxa in the species complex, but it also exhibits considerable variation that is reflected in subspecific groupings (Serrano, 1988; Matalin, 1998). However, the clinal variation along the Portuguese coast presents difficulties for defining subspecific divisions in a traditional manner. Serrano (1988) separated the two subspecies according to the "75 percent rule" based on differences in general body colouration, elytral maculation and microsculpture of pronotum and elytra. This method recognises a population as a valid subspecies if 75 percent of the individuals differ from "all" (97 percent) of the individuals assigned to another subspecies (Mayr, 1969). In the most recent taxonomic revision of the group, Matalin (1998) also considered the existence of two subspecies: C. l. lusitanica Mandl, 1935 (=C. hybrida lusitanica Mandl, 1935 sensu Serrano, 1988) and C. l. silvaticoides W. Horn, 1937 (=C. h. algarbica Serrano, 1988 sensu Serrano, 1988). However, both authors had difficulties in defining subspecific limits in the intermediate range of distribution of the species, with a problematic group of populations called "intergrade" (Serrano, 1988) or "possible transition zone" (Matalin, 1998).

For the taxonomic recognition of subspecies in C. lusitanica, variation in dorsal colour patterns was essential (Serrano, 1988; Matalin, 1998). Elytral colour variation in tiger beetles is thought to optimise background matching, an important antipredation strategy (Schultz, 1986; Knisley \& Schultz, 1997). In addition, elytral colour variation is highly important for thermoregulation (Acorn, 1992). Therefore, differences in elytral colouration may be a consequence of environmental differences (Morgan et al., 2000), and hence may not reflect deep historical separation of lineages.

As the typical habitat of $C$. lusitanica in the secondary dune systems along the coast is increasingly affected by anthropogenic disturbance and development, the species has been in general decline. In addition, habitat fragmentation is presumably causing disruption of gene flow patterns. As conservation programmes might have to be implemented, it is of great importance to establish proper taxonomic groupings, as the basis for the implementation of conservation strategies. However, due to the gradual morphological variation, clearly distinct taxonomic groupings may not be recognisable.

The evaluation of diversity patterns in a cline and the delimitation of potential conservation units were attempted by Vogler \& DeSalle (1994) in a similar situation for the endangered $C$. dorsalis which is distributed in a latitudinal gradient along 
the North American coast. Population Aggregation Analysis (PAA; Davis \& Nixon, 1992) was used to separate distinct units on the basis of unique attributes (diagnostic characters). The method has since been applied successfully in several other studies on different groups of organisms (e.g., Legge et al., 1996; Birstein et al., 1998; Barrat et al., 1999; Doukakis et al., 1999; Wyner et al., 1999; Williams, 2002).

The diagnosability criterion and the PAA procedure provide an objective methodology for the assessment of units of biological diversity where variation is discrete, but are not directly applicable when geographic variation is clinal, as the procedure will aggregate all populations with some overlap in genotypes in a single unit even if geographically distant groups in the cline are highly divergent. A possibility of separating such clinal variation is to make projections about the extinction of intermediate "linker" populations and test for the presence of diagnosable entities if such populations have been removed (Vogler, 1994; Vogler, 1998; Goldstein et al., 2000). The application of this procedure to the assessment of clinal variation may be particularly appropriate in the case of endangered species where it incorporates the effect of population extinction into the delimitation of conservation units.

Here we evaluated the pattern of morphological and molecular variation within and between six populations of $C$. lusitanica. We used this information to: i) validate the infraspecific taxonomic ranking traditionally recognised, mainly by means of a multivariate analysis of the morphological data; ii) determine if the morphological groupings are recognised as phylogenetic groups based on mtDNA differentiation within and between populations; iii) assess the presence of distinct units along the geographic cline by using the approach outlined above, and iv) propose groupings for separate conservation management on the basis of the observed variation.

\section{Materials and Methods}

\section{MORPHOMETRIC ANALYSIS}

A total of eight measurements (linear distances) obtained from 59 males of $C$. lusitanica were analysed. These included four measurements taken on elytral macula, as originally presented in Serrano (1988): distance between distal end of humeral lunule and middle band (DHM), width of middle band (WM), distance between middle band and ely- tral margin (DME) and distance between distal end of middle band and apical lunule (DMA). Four new measurements collected in this study were: total length of right elytron (LE), width of elytra (WE), length of male genitalia (LMG) and width of male genitalia (WMG). The sample analysed was represented by ten specimens from each of five populations: Amorosa (AMO), São Pedro de Moel (SPM), Melides (MEL), Ribeira da Azenha (RAZ), Carrapateira (CAR) and by nine specimens from Almograve-Zambujeira do Mar (ALM). These populations included representatives of $C$. l. lusitanica (AMO, SPM, MEL and RAZ), C. l. silvaticoides (CAR) and from the intergrade region (ALM).

Morphological discrimination between individuals and between groupings of individuals was assessed by means of multivariate analysis of the morphometric data. We performed a Principal Component Analysis (PCA) and a Canonical Variate Analysis (CVA) using STATISTICA version 6 (StatSoft, 2002). One of the main differences between PCA and CVA is that the former maximises the differences among specimens while the latter maximises the differences among groups of specimens.

In the PCA, principal components (PC) were derived from a covariance data matrix calculated from the original $\log _{n}$ transformed data. Plots of the projection of the variables (measurements) and of the cases (individuals) on the planes of the retained PCs (only, PC1 versus $\mathrm{PC} 2$ and $\mathrm{PC} 1$ versus PC3) were obtained and used to discuss the structure within the data, i. e. the contribution of each variable (measurement) to discriminate between individuals. The CVA was performed on the $\log _{n}$ transformed data, and, the plots obtained for the canonical variate $(\mathrm{CV})$ scores on the first three CVs (CV1 versus CV2 and CV1 versus CV3) were analysed for evidence of discrimination between groups of specimens.

\section{DNA ANALYSIS}

A total of 53 specimens were analysed with 48 specimens of $C$. lusitanica and five representing other (sub)species of the $C$. hybrida complex used as outgroups (Table 1). C. lusitanica was represented by six populations, AMO, SPM, MEL, RAZ, ALM and CAR, identical to those used in the morphometric analysis. The other species or subspecies of the C. hybrida group were named $\mathrm{H} 1$ to $\mathrm{H} 5$ for simplicity and to clearly distinguish them from $C$. lusitanica populations (the main subject of the present study). Sample size is fairly modest (particularly for AMO and RAZ) and the reader should be 
Table 1.- Assigned taxa, sampling sites, site coordinates, collectors, population codes and sample sizes (N) for the specimens used in this study.

Tabla 1.- Taxones asignados, localidades de muestreo, coordenadas geográficas, recolectores, códigos de población y tamaños muestrales $(\mathrm{N})$ de los especímenes usados en este estudio.

\begin{tabular}{|c|c|c|c|c|c|}
\hline Species/ Subspecies & Sampling locality & Coordinates & Collector & Population code & $\mathbf{N}$ \\
\hline C. l. lusitanica & Portugal, Viana do Castelo, Amorosa & $41^{\circ} 39.01^{\prime} \mathrm{N}, 08^{\circ} 49.45^{\prime} \mathrm{W}$ & A. Cardoso & $\mathrm{AMO}$ & 5 \\
\hline C. l. lusitanica & Portugal, Leiria, São Pedro de Moel & $39^{\circ} 46.95^{\prime} \mathrm{N}, 09^{\circ} 01.11^{\prime} \mathrm{W}$ & A. Cardoso & SPM & 7 \\
\hline C. l. lusitanica & Portugal, Setúbal, Melides & $38^{\circ} 08.11^{\prime} \mathrm{N}, 08^{\circ} 47.31^{\prime} \mathrm{W}$ & A. Cardoso & MEL & 9 \\
\hline C. l. lusitanica & Portugal, Beja, Ribeira da Azenha & $37^{\circ} 47.91^{\prime} \mathrm{N}, 08^{\circ} 47.30^{\prime} \mathrm{W}$ & A. Cardoso & RAZ & 5 \\
\hline$?^{(1)}$ & Portugal, Beja, Almograve- Zambujeira do Mar & $37^{\circ} 38.22^{\prime} \mathrm{N}, 08^{\circ} 47.50^{\prime} \mathrm{W}$ & A. Cardoso & ALM & 12 \\
\hline C. l. silvaticoides & Portugal, Faro, Carrapateira & $37^{\circ} 11.52^{\prime} \mathrm{N}, 08^{\circ} 54.06^{\prime} \mathrm{W}$ & A. Cardoso & CAR & 10 \\
\hline C. hybrida ${ }^{(2)}$ & Spain, Cantabria, Noja, Playa de Helgueras & & P. Bahillo & H1 & 1 \\
\hline C. hybrida ${ }^{(2)}$ & Spain, Pyrenees, Monte Perdido & & A. Cardoso & $\mathrm{H} 2$ & 1 \\
\hline C. hybrida ${ }^{(2)}$ & Germany, Freising Savoyer Au & & J. Schindler & $\mathrm{H} 3$ & 1 \\
\hline C. hybrida ${ }^{(2)}$ & Germany, Wolfrothansen Pupplinger Au & & U. Heckes & $\mathrm{H} 4$ & 1 \\
\hline C. hybrida ${ }^{(2)}$ & Germany, Sachsen-Anhalt Drosede S Wittenberge/ Elbe & & J. Wiesner & H5 & 1 \\
\hline
\end{tabular}

(1) represents the "intergrade" region defined by Serrano (1988)

(2) representatives of other species or subspecies belonging to $C$. hybrida complex.

aware of the limitations of the data set in what concerns statistical treatment for population level studies and the preliminary nature of this approach.

Total genomic DNA was extracted from each specimen (thorax or legs) preserved in absolute ethanol at $-20^{\circ} \mathrm{C}$, using a phenol-chloroform protocol (Vogler et al., 1993). PCR amplification and sequencing followed Vogler et al. (1993) with slight modifications of the amounts of primer and genomic DNA used in the PCR master mix and in the cycle conditions. DNA fragments were sequenced using an ABI PRISM ${ }^{\mathrm{TM}} 3700$ DNA Analyzer (Applied Biosystems). A fragment of 730 base pairs of Cytochrome Oxidase I (COI) gene was amplified using the primers C1-J-2183 and TL2-N3014 (Simon et al., 1994). Sequences were manually edited using Sequencher version 4.1.2 (Gene Codes Corporation, 2000). Haplotypes were deposited in GenBank under accession numbers AJ583533-AJ583541.

Phylogenetic relationships among haplotypes were established by parsimony analysis using PAUP version 4.0b10 (Swofford, 2002), performing an exhaustive search with all characters unordered and of equal weight. Branching confidence levels were estimated as bootstrap values for 1000 replicates. The trees were rooted based on evidence from a phylogenetic analysis of a wider sample of the C. hybrida group (unpublished data). Character changes were mapped on the cladogram in MacClade version 4.0 (Maddison \& Maddison, 2000) using the trace character option for all possible changes. Levels of intra and inter- populational genetic divergence were calculated based on uncorrected pairwise distances between haplotypes.

\section{Population Aggregation Analysis}

PAA (Davis \& Nixon, 1992) was implemented to search for diagnosable entities within C. lusitanica based on the identification of diagnostic characters. In this approach variation in nucleotide positions in the COI data matrix was analysed among individuals within and between populations, which allowed to differentiate between traits (variable and polymorphic states within populations) and characters (fixed nucleotide states within populations). If all members of a population shared a particular attribute not shared with any individuals from other populations, those individuals would be considered to represent a diagnosable unit. If several populations possessed that attribute shared by all members of such populations but not shared with individuals in any other populations they were "aggregated" into the same diagnosable entity.

\section{Results}

MORPHOMETRIC ANALYSIS

The first three principal components represented $95.92 \%$ of the total variation within the data set $(75.36 \%, 15.16 \%$ and $5.40 \%$ for the first, second, and third axes, respectively). The projection of variables according to $\mathrm{PC} 1$ versus $\mathrm{PC} 2$ showed that 

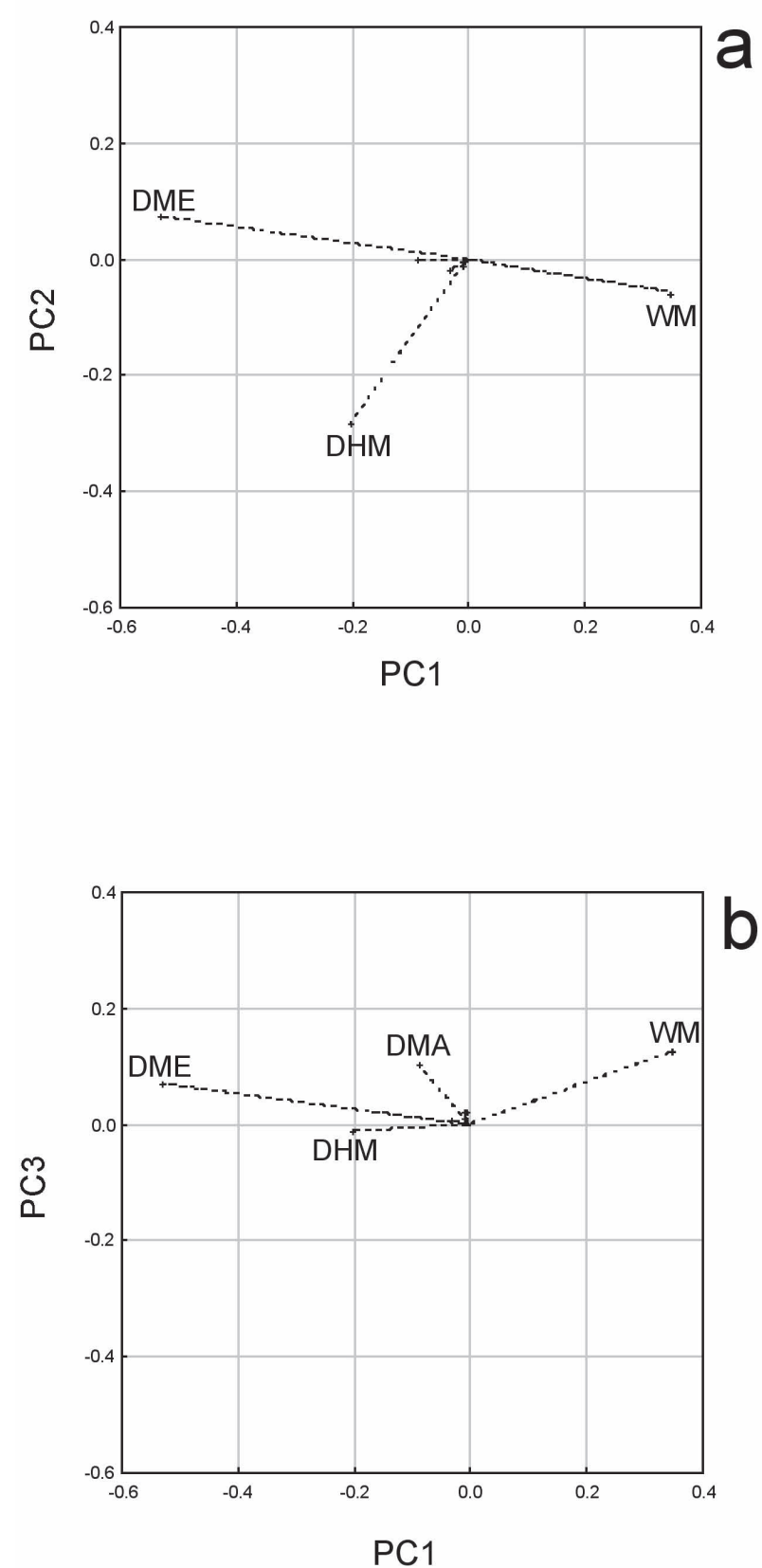

Fig. 1.- Plots of the projection of measurements taken from specimens of Cicindela lusitanica onto the planes of the first three Principal Components: PC1 versus PC2 (a) and PC1 versus PC3 (b).

Fig. 1.- Representación gráfica de las proyecciones de las medidas obtenidas a partir de los especímenes de Cicindela lusitanica sobre los planos de las tres primeras Componentes Principales: PC1 versus PC2 (a) y PC1 versus PC3 (b). variables WM and DME were the most relevant for the ordination of individuals along the first PC axis, although with opposite polarity and slightly different magnitude (Fig. 1a). In the ordination along the second $\mathrm{PC}$ axis the most important variable was DHM (Fig. 1a). In the ordination space of PC1 versus PC3, WM and DMA were the two variables with major contribution for the ordination of individuals along the third PC3 axis (Fig. 1b).

Figure 2 represents the distribution of $\mathrm{PC}$ scores for all individuals analysed. The plot PC1 versus PC2 showed a broad range of variation along PC1 axis, with only the individuals from population CAR from the most southern end of the range forming a distinct cluster while the other five populations showed overlapping distributions (Fig. 2a). The position on axis $\mathrm{PC} 1$ indicates that population CAR was represented by individuals with large values of DME and low values of WM. No separation of populations was evident along PC2. There were two individuals that were separated from all others (Af and Ba in Fig. 2a). Their position in the plot indicated greatly reduced DHM values, which was confirmed from the raw data. In the distribution of individuals in the ordination space $\mathrm{PC} 1$ versus $\mathrm{PC} 3$ no further discrimination of distinct groups was apparent along the third PC axis (Fig. 2b). We also repeated the analysis removing the two apparent outliers, but this had little effect on the projections of the variables and the distribution of individuals in the ordination space (not shown).

In the Canonical Variate Analysis, the first three canonical variates contributed $98.37 \%$ of the total variation in the data, with $61.51 \%$ attributed to the first, $24.11 \%$ to the second, and $12.75 \%$ to the third $\mathrm{CV}$. In the plot CV1 versus CV2 there is clear discrimination between populations, with the separation of individuals from population SPM, population CAR, and a group of the remaining four populations (Fig. 3a). In the plot of CV1 versus CV3, population AMO was also recognisably separated from the central cluster of populations (Fig. 3b). Removing the potential outliers (individuals Af and Ba, see Fig. 2a) did not greatly affect the CVA.

\section{Phylogenetic AnALYsis}

The analysis of COI sequences revealed the presence of nine haplotypes differing in 26 positions. Four haplotypes were found exclusively in C. lusitanica populations (designated L1-L4), whereas the remaining five were exclusive to the other (sub)species of C. hybrida complex (H1-H5) (Table 2). Haplotypes L1 and L4 were widely distributed (haplotype L1 was found in populations AMO, 

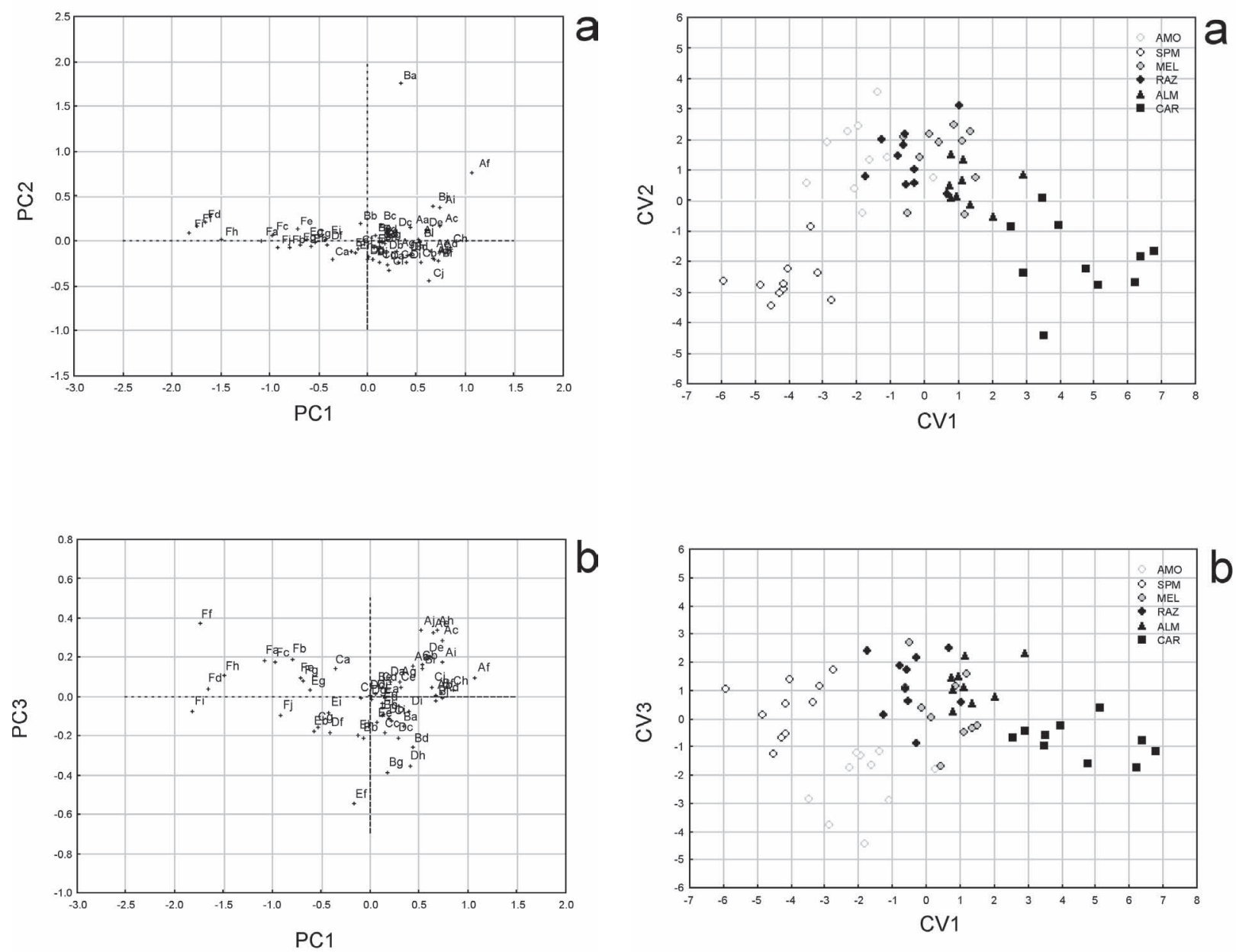

Fig. 2.- Plots of the scores for the first three Principal Components for the morphological analysis of 59 specimens of Cicindela lusitanica: PC1 versus PC2 (a) and PC1 versus PC3 (b). Each individual is represented by a capital letter identifying the population (A-AMO, B-SPM, C-MEL, D-RAZ, EALM and F-CAR) followed by a small letter representing a particular specimen $(\mathrm{a}-\mathrm{j})$.

Fig. 2.- Representación gráfica de los valores para los tres primeros Componentes Principales del análisis de 59 especímenes de Cicindela lusitanica: PC1 versus PC2 (a) y PC1 versus PC3 (b). Cada individuo está representado por una letra mayúscula identificando la población (A-AMO, B-SPM, CMEL, D-RAZ, E-ALM y F-CAR) y una letra minúscula correspondiente a cada espécimen en particular (a-j).

SPM and MEL and haplotype L4 in populations RAZ, ALM and CAR). In contrast, haplotype L2 was exclusively found in population MEL, and haplotype L3 was limited to population ALM (Table 2). Sequence divergence within C. lusitanica

Fig. 3.- Plots of the scores for the first three Canonical Variates: CV1 versus CV2. (a) and CV1 versus CV3 (b). Circles in different tonalities represent the several populations of C. l. lusitanica, triangles populations of the intergrade zone and squares the $C$. l. silvaticoides population.

Fig. 3.- Representación gráfica de los valores de las tres primeras Variables Canónicas: CV1 versus CV2 (a) y CV1 versus CV3 (b). Los círculos de diferente tonalidad representan poblaciones de C. l. lusitanica, los triángulos las de la "zona de transición", y los cuadrados la de C. l. silvaticoides.

ranged from 0 to $0.27 \%$ within populations and from 0 to $0.43 \%$ between populations (Table 3 ). The divergence between $C$. lusitanica and $C$. hybri$d a$ haplotypes was much higher, ranging from 0.84 to $2.59 \%[1.75 \pm 0.45]$. 
Table 2.- Nucleotide sequences of the mtDNA COI haplotypes included in the present analysis and haplotype frequencies in each population of $C$. lusitanica. Only variable positions are shown. A dot indicates identity with the haplotype L1.

Tabla 2.- Secuencias nucleotídicas de los haplotipos COI mitocondriales incluidos en el presente análisis y frecuencias haplotípicas para cada población de $C$. lusitanica. Únicamente se muestran las posiciones variables. Un punto señala identidad de secuencia con el haplotipo L1.

\begin{tabular}{|c|c|c|c|c|c|c|c|}
\hline \multicolumn{2}{|r|}{ Position } & \multicolumn{6}{|c|}{ Population (N individuals) } \\
\hline Haplotype & 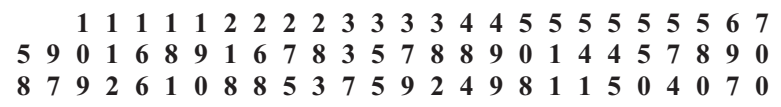 & AMO & SPM & MEL & RAZ & ALM & CAR \\
\hline L1 & C T G A T C A C G T T C G G C T G A A T G C A A T G & 5 & 7 & 2 & & & \\
\hline $\mathrm{L} 2$ & . . $\mathrm{T} . \mathrm{T} . .$. & & & 7 & & & \\
\hline L3 & . . & & & & & 2 & \\
\hline L4 & . $\mathrm{T}$ & & & & 5 & 10 & 10 \\
\hline H1 & A. C. . & & & & & & \\
\hline $\mathrm{H} 2$ & $\mathrm{CAG} \cdot \mathrm{T} \mathrm{GATC} \cdot \mathrm{TA} . \mathrm{T}$ & & & & & & \\
\hline H3 & $. \mathrm{CA} \cdot \mathrm{C} \mathrm{TG} . \mathrm{TC} . \mathrm{TA} \ldots \mathrm{AGG}$. & A & & & & & \\
\hline $\mathrm{H} 4$ & $\therefore \mathrm{A} \cdot \mathrm{C} \mathrm{T} \mathrm{G} \cdot \mathrm{T} \mathrm{C} \cdot \mathrm{T} \cdot \mathrm{A} \mathrm{T} \cdot \mathrm{A}$. & & & & & & \\
\hline H5 & T. T C.T.A.CA & & & & & & \\
\hline
\end{tabular}

The phylogenetic analysis of the nine haplotypes resulted in a single most parsimonious cladogram of 30 steps (C.I. $=0.867$, R.I. $=0.879$; Fig. 4). All C. lusitanica haplotypes were monophyletic and distinguished from the C. hybrida clade by two synapomorphies (positions 499 and 700). Within this clade, haplotypes L3 and L4 formed a monophyletic group supported by a single synapomorphy (nucleotide position 545), with haplotypes L1 and L2 basal to them. Furthermore, there was clear geographic structure in the distribution of $C$. lusitanica haplotypes. Haplotype L1 was almost exclusively found in the two most northern populations (AMO and SPM) although with a few representatives in MEL, at the southern end of the northern group of populations (Figs. 4 and 5). Haplotype L2 occurred exclusively in population MEL. Haplotypes L3 and L4 were unique to the southern populations. With respect to the traditionally recognised taxa, haplotypes L1 and L2 were confined to C. l. lusitanica, haplotype L3 was exclusive to the intergrade region, and haplotype L4 was represented in C. l. silvaticoides, in the intergrade region and in C. l. lusitanica.

Table 3.- Pairwise measures of genetic divergence between Cicindela lusitanica haplotypes. Average \pm standard deviation and minimum and maximum values (between brackets) are given in percentages (\%).

Table 3.- Medidas de divergencia genética entre pares de haplotipos en Cicindela lusitanica. Media \pm desviación estándar y valores mínimos y máximos (entre paréntesis) se dan en porcentajes (\%).

\begin{tabular}{|c|c|c|c|c|c|c|}
\hline & AMO & SPM & MEL & RAZ & ALM & CAR \\
\hline AMO & 0 & & & & & \\
\hline SPM & 0 & 0 & & & & \\
\hline MEL & $\begin{array}{c}0.214 \pm 0.138 \\
(0-0.281)\end{array}$ & $\begin{array}{c}0.214 \pm 0.115 \\
(0-0.278)\end{array}$ & $\begin{array}{c}0.107 \pm 0.135 \\
(0-0.274)\end{array}$ & & & \\
\hline RAZ & $\begin{array}{c}0.276 \pm 0.004 \\
(0.274-0.283)\end{array}$ & $\begin{array}{c}0.275 \pm 0.001 \\
(0.274-0.278)\end{array}$ & $\begin{array}{c}0.274 \pm 0 \\
(0.274-0.275)\end{array}$ & 0 & & \\
\hline ALM & $\begin{array}{c}0.299 \pm 0.053 \\
(0.274-0.433)\end{array}$ & $\begin{array}{c}0.298 \pm 0.053 \\
(0.274-0.424)\end{array}$ & $\begin{array}{c}0.297 \pm 0.052 \\
(0.274-0.417)\end{array}$ & $\begin{array}{c}0.023 \pm 0.052 \\
(0-0.140)\end{array}$ & $\begin{array}{c}0.042 \pm 0.064 \\
(0-0.140)\end{array}$ & \\
\hline CAR & $\begin{array}{c}0.278 \pm 0.005 \\
(0.274-0.288)\end{array}$ & $\begin{array}{c}0.277 \pm 0.004 \\
(0.274-0.286)\end{array}$ & $\begin{array}{c}0.276 \pm 0.003 \\
(0.274-0.285)\end{array}$ & 0 & $\begin{array}{c}0.023 \pm 0.052 \\
(0-0.147)\end{array}$ & 0 \\
\hline
\end{tabular}




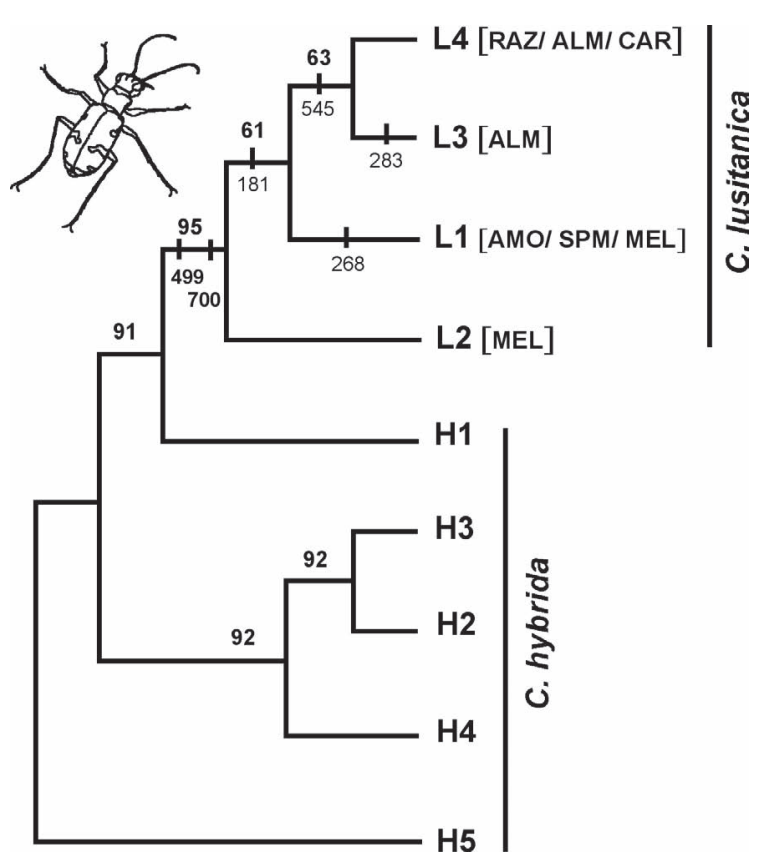

Fig. 4.- Phylogenetic relationships among mtDNA COI haplotypes. C. lusitanica haplotypes are represented by L1-L4 and the other species belonging to $C$. hybrida complex are represented by H1-H5. The three letter code in bold represents the geographic distribution of the $C$. lusitanica haplotypes recognised. Nucleotide substitutions between $C$. lusitanica haplotypes are represented by dash marks and the respective nucleotide position labelled below. The positions shown in bold represent the synapomorphies that distinguish C. lusitanica from C. hybri$d a$ haplotypes. The numbers at the nodes above branches indicate the bootstrap values that received support $>50 \%$.

Fig. 4.- Relaciones filogenéticas entre haplotipos de COI. Los haplotipos de $C$. lusitanica se representan mediante L1-L4 y los de otras especies pertenecientes al complejo $C$. hybrida mediante H1-H5. El código de tres letras en negrita corresponde a la distribución geográfica de los haplotipos observados en C. lusitani$c a$. Las substituciones nucleotídicas entre haplotipos de C. lusitanica se indican mediante trazos con la correspondiente posición nucleotídica señalada en la parte inferior. Las posiciones destacadas en negrita representan las sinapomorfías que diferencian los haplotipos de C. lusitanica de los de C. hybrida. Los números sobre las ramas indican los valores de bootstrap superiores al $50 \%$.

\section{Population Aggregation Analysis}

PAA on the $C$. lusitanica haplotypes revealed only one diagnostic character (position 545; Table 4) which diagnosed the northern populations (AMO, SPM and MEL) as distinct from the three most southern ones (RAZ, ALM and CAR). The other variable nucleotide positions $(181,268$ and

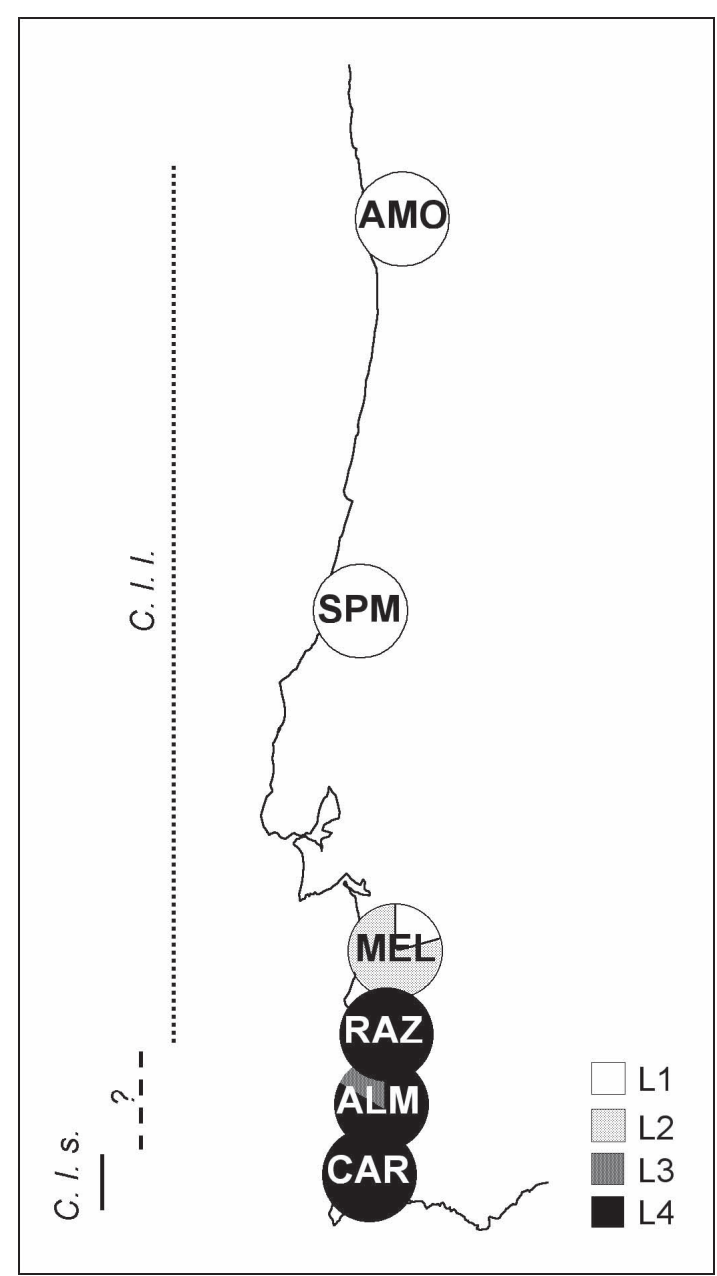

Fig. 5.- Geographic distribution of Cicindela lusitanica COI haplotypes along the Portuguese coastline. Chart pies represent haplotype frequencies for the six populations. The range of each recognised taxon, C. l. lusitanica (C. l. l.), C. l. silvaticoides (C. l. s.) and the intergrade zone (?) are identified with different dashed lines.

Fig. 5.- Distribución geográfica de los haplotipos de COI en Cicindela lusitanica a lo largo de la costa Portuguesa. Los gráficos circulares representan las frecuencias de haplotipos para las seis poblaciones. Los ámbitos de distribución de cada taxón reconocido, C. l. lusitanica (C. l. l.), C. l. silvaticoides (C. l. s.) y la "forma de transición" (?) se identifican con líneas de trazo diferente.

283) did not identify any population or group of populations as a distinct entity. Variation at positions 181 and 283 was confined to MEL and ALM, respectively, indicating alleles private to these populations. The distribution of variation in position 268 was peculiar, with a $G$ at this site for the northern populations, $\mathrm{T}$ for the southern popula- 
Table 4.- Population Aggregation Analysis representation. Only nucleotide substitutions within Cicindela lusitanica are represented. Populations are ordered in the North-South gradient. The diagnostic site is represented in bold.

Tabla 4.- Representación del análisis de agregación poblacional. Sólo se representan las substituciones nucleotídicas en Cicindela lusitanica. Las poblaciones se presentan ordenadas en el gradiente Norte-Sur. La posición diagnóstica se representa en negrita.

\begin{tabular}{lclcccc}
\hline & \multicolumn{7}{c}{ C. lusitanica populations } \\
\cline { 2 - 7 } position & AMO & SPM & MEL & RAZ & ALM & CAR \\
\hline 181 & $\mathrm{C}$ & $\mathrm{C}$ & $\mathrm{C} / \mathrm{T}$ & $\mathrm{C}$ & $\mathrm{C}$ & $\mathrm{C}$ \\
268 & $\mathrm{G}$ & $\mathrm{G}$ & $\mathrm{G} / \mathrm{T}$ & $\mathrm{T}$ & $\mathrm{T}$ & $\mathrm{T}$ \\
283 & $\mathrm{~T}$ & $\mathrm{~T}$ & $\mathrm{~T}$ & $\mathrm{~T}$ & $\mathrm{C} / \mathrm{T}$ & $\mathrm{T}$ \\
$\mathbf{5 4 5}$ & $\mathbf{G}$ & $\mathbf{G}$ & $\mathbf{G}$ & $\mathbf{A}$ & $\mathbf{A}$ & $\mathbf{A}$ \\
\hline
\end{tabular}

tions, and both states represented at population MEL located in an intermediate position.

\section{Discussion}

\section{MORPHOMETRIC CHARACTERISATION}

The PCA revealed that a very large proportion of the total variation was accounted for by the first principal component representing mostly the shape of elytral maculae (measurements for WM and DME). These variables correspond to two of the four characters used for the subspecies ranking by Serrano (1988). The other macula characters as well as the four characters used for the characterisation of overall size and male genitalia were not as effective for the population discrimination.

The PCA clearly separates the specimens of population CAR along the $\mathrm{PC} 1$ as a separate group, consistent with its current taxonomic status as a separate subspecies, C. l. silvaticoides. However, the separation from the other populations is marginal, and overall these remaining populations include a greater diversity than CAR. The individuals more similar to CAR are predominantly from the geographically closest populations, including the populations of the intergrade area (ALM). The arrangement of the remaining individuals along $\mathrm{PC} 1$ axis is somewhat clinal, with individuals from the northern populations AMO, SPM and MEL generally more distinct from the $C$. l. silvaticoides population. Hence, it appears that PC1 captures the variation that has been recognised before based on qualitative analysis of elytral patterns.

As there was fairly high variation within populations, relative to between populations variation, along the cline we also attempted to capture the differentiation between the various populations in a Canonical Variate Analysis. This approach separated populations further (in addition to CAR) and discriminated either one (SPM in CV1 versus CV2) or both (AMO and SPM in CV1 versus CV3) of the northern populations from the remaining cluster (MEL, RAZ, ALM). The latter are found in relatively close proximity, and include the intergrade population.

In summary, the morphometric analyses based on both statistical approaches support the idea of a morphological latitudinal cline as proposed by Serrano (1988), with rather distinct groupings in particular at the very southern end (C. l silvaticoides), but also some degree of differentiation between the distant northern populations (AMO and SPM). The remaining three populations are very similar morphologically both when analysed for between individuals and between populations variation. Our analyses supported the subspecific status attributed to population CAR (Serrano, 1988) but put into question the geographic limits of C. l. lusitanica.

MTDNA VARIATION AND PHYLOGEOGRAPHIC PATTERN

The mtDNA analysis revealed that $C$. lusitanica populations are well distinguished from others in the C. hybrida complex. Furthermore, C. lusitanica populations exhibited low levels of sequence divergence and a small number of haplotypes represented by a few variable nucleotide positions. However, genetic variation was structured, essentially separating the three southern and three northern populations by unique haplotypes, plus the two intermediate populations (ALM and MEL) also exhibiting characteristic haplotypes exclusive to each of them. This geographic structure is not in 
agreement with the pattern of morphological variation in the multivariate analysis, nor with the taxonomic entities proposed previously, which split the groupings differently (Fig. 4).

The discrepancies of mtDNA and morphological markers (the latter presumably reflecting patterns of character variation in nuclear markers) could be due to a variety of causes. These include "neutral" patterns of variation resulting from historical processes of lineage sorting or population hybridisation which generally affect closely related populations or species. Alternatively, the morphological differentiation may be driven by selection due to environmental factors, including thermoregulation (Acorn, 1992) and predation (Schultz, 1986; Knisley \& Schultz, 1997). Further investigations of genetic markers, in particular nuclear genes, as well as habitat parameters such as substrate colouration, grain size and temperature would have to be conducted to discriminate between these possibilities. It is, however, intriguing that morphological differences are partly correlated with geographic distance, as the rather isolated and distant northern populations are more distinct than the three adjacent southern populations (except for the discretely distinct $\mathrm{CAR}$ ). In contrast, the pattern of genetic variation does not seem to be determined primarily by geographic distance, although some geographic structure exists in mtDNA, both locally (evident from the alleles private to a single population) and over larger scales (evident from the two groups of mtDNA). In sum, these observations may suggest a pattern of generally limited gene flow between populations and processes of differentiation that are accentuated by local adaptations and occasional long-term separation events.

\section{ASSESSMENT OF POTENTIAL CONSERVATION UNITS}

As different markers (mtDNA and morphology) have been affected differently by the differentiation process outlined above, it is difficult to capture the underlying variation in a unified taxonomic classification. By separating the distinct $C$. l. silvaticoides, the current taxonomy emphasises the morphological differentiation, but this classification at the same time is arbitrary in naming only the most distinct population (CAR) rather than others, which can also be separated with statistical methods. Alternatively, the taxonomy of the group could be established based on the two diagnosable mtDNA types which, however, would lump morphologically distinct groups while separating some that are morphologically indistinguishable. None of these alternative classification schemes would be fully satisfactory.
Similarly, this situation provides difficulties for establishing appropriate groupings for conservation. The application of the diagnosability criterion assumes that discrete entities can be discovered, providing an objective, yet contentious, methodology to determine what should be conserved. If no discrete entities exist, or if various character systems contradict each other in delimiting these entities, as is the case here, the notion of diagnosability reaches its limits. However, in the case of $C$. lusitanica both the mtDNA and morphology broadly agree in that there is substantial variation between populations. Therefore it would not be adequate to treat this entire assemblage as uniform.

The approach adopted here considers a case where the diagnosability criterion is extended to situations of gradual or clinal variation. In such cases, "linker" populations, defined as those in an intermediate geographical position relative to sets of populations that are diagnosably distinct, are identified. Removing these populations, and simulating their extinction, would result in the recognition of diagnosable entities among the remaining populations (Vogler, 1998; Williams, 2002). Projections of population extinction could therefore be used to test potential recovery of diagnosable populations in the remaining assemblage in a cline, providing a criterion for conservation priority. If this procedure is applied to $C$. lusitanica, both mtDNA and morphological variation agree that the populations at the extreme ends of the range are discretely different. This sets a minimum of two separate groupings, corresponding to any of the northern populations (AMO and SPM) as well as the southern C. l. silvaticoides (population CAR). Additional groupings could perhaps be separated with increased DNA sequencing as greater genetic resolution might reveal hidden DNA differentiation, for example in the morphologically separable northern populations. However, denser sampling may also have the opposite effect, as populations intermediate to those currently sampled could provide evidence for a less stringently stepped variation than it is observed in the current data set. For example, the diagnostic variation based on nucleotide site 541 could turn out to be clinal when additional populations from the boundary area are included.

\section{Conclusions}

The establishment of entities for conservation requires objective and unambiguous criteria. Particularly interesting are cases where variation is 
not discrete but following a clinal fashion. In this study, attributing taxonomic designations is not straightforward. However, by applying the diagnosability criterion and the tests for "linker" populations it was possible to determine the groups within C. lusitanica which are defined morphologically and genetically. We conclude that a northern (with populations AMO and SPM) and a southern (with only CAR) group should be provisionally considered separate conservation units.

\section{ACKNOWLEDGMENTS}

Our thanks to the editors of Graellsia for the invitation to participate in this special volume in homage to Fermín MartínPiera, which was a friend and a reference for one of us (A. S.). We thank the collectors referred in the text for the samples supplied, Miquel Palmer and Clive Moncrieff for suggestions on the multivariate analysis, Jesús Gómez-Zurita for comments on an earlier draft of the manuscript, valuable discussions and Spanish translation. Funding for a PhD stipend to A. C. was provided by Fundação para a Ciência e a Tecnologia (PRAXIS XXI/ BD/ 18409/ 98).

\section{References}

ACoRn, J. H., 1992. The Historical Development of Geographic Color Variation among dune Cicindela in Western Canada (Coleoptera: Cicindelidae). In: G. R. Noonan, G. E. Ball \& N. E. Stork (eds.).The Biogeography of Ground Beetles of Mountains and Islands. Intercept. Andover: 217-234.

Barrat, E. M., Gurnell, J., Malarky, G., Deaville, R. \& BRUFFORD, M. W., 1999. Genetic structure of fragmented populations of red squirrel (Sciurus vulgaris) in the UK. Molecular Ecology, 8: S55-S63.

Birstein, V. J., Doukakis, P., Sorkin, B. \& Desalle, R., 1998. Population Aggregation Analysis of three Caviar-Producing Species of Sturgeons and Implications for the Species Identification of Black Caviar. Conservation Biology, 12(4): 766-775.

Davis, J. I. \& NixON, K. C., 1992. Populations, Genetic Variation, and the Delimitation of Phylogenetic Species. Systematic Biology, 41(4): 421-435.

Doukakis, P., Birstein, V. J., Ruban, G. I. \& Desalle, R., 1999. Molecular genetic analysis among subspecies of two Eurasian sturgeon species, Acipenser baerii and A. stellatus. Molecular Ecology, 8: S117-S127.

GEBERT, J., 1995. Revision der Cicindela (s. str.) hybridaGruppe (sensu MANDL 1935/6) und Bemerkungen $\mathrm{zu}$ einigen auBerlich ahnlichen palaarktischen Arten (Coleoptera, Cicindelidae). Mitteilungen der Munchner Entomologischen Gesellschaft, 86: 3-32.

GeBert, J., 1999. Erster Nachtrag und Berichtigung zur "Revision der Cicindela (s. str.) hybrida-Gruppe (sensu MANDL 1935/36)". Nachrichtenblatt der Bayerischen Entomologen, 48: 3-4.

Gene Codes Corporation, 2000. Sequencher version 4.1.2. Ann Arbor, MI, USA.

Goldstein, P. Z., Desalle, R., Amato, G. \& Vogler, A. P., 2000. Conservation Genetics at the Species Boundary. Conservation Biology, 14(1): 120-131.

Knisley, C. B. \& Schultz, T. D., 1997. The Biology of Tiger Beetles and a Guide to the Species of the South Atlantic States. Virginia Museum of Natural History. Virginia. $210 \mathrm{pp}$.

Legge, J. T., Roush, R., Desalle, R., Vogler, A. P. \& MAY, B., 1996. Genetic Criteria for Establishing Evolutionarily Significant Units in Cryan's Buckmoth. Conservation Biology, 10(1): 85-98.

Maddison, D. R. \& Maddison, W. P., 2000. MacClade 4.0. Sinauer Associates, Inc. Sunderland.

Matalin, A. V., 1998. The tiger-beetles of "hybrida"-species group (Coleoptera, Carabidae. Cicindelinae). III. A taxonomic review of the Iberian Cicindela lagunensis Gautier, 1872 complex. Graellsia, 54: 75-96.

Mayr, E., 1969. Principles of Systematic Zoology. Mc.Graw-Hill Inc. New York. 428 pp.

Morgan, M., Knisley, C. B. \& Vogler, A. P., 2000. New Taxonomic Status of the Endangered Tiger Beetle Cicindela limbata albissima (Coleoptera: Cicindelidae): Evidence from mtDNA. Annals of the Entomological Society of America, 93(5): 1108-1115.

Schultz, T. D., 1986. Role of Structural Colors in Predator Avoidance by Tiger Beetles of the Genus Cicindela (Coleoptera: Cicindelidae). Bulletin of the Entomological Society of America, 32: 142-146.

Serrano, A. R. M., 1988. Contribution to the knowledge of Cicindela hybrida lusitanica Mandl, 1935 (Coleoptera, Cicindelidae) and description of a new subspecies, C. hybrida algarbica n. ssp. from Algarve.- Portugal. Boletim da Sociedade Portuguesa de Entomologia, 95: 1-15.

Simon, C., Frati, F., Beckenbach, A., Crespi, B., Liu, H. \& FLOOK, P., 1994. Evolution, Weighting, and Phylogenetic Utility of Mitochondrial Gene Sequences and a Compilation of Conserved Polymerase Chain Reaction Primers. Annals of the Entomological Society of America, 87(6):651-701.

STATSOFT, InC., 2002. STATISTICA (data analysis software system), version 6 . www.statsoft.com

Swofford, D. L., 2002. PAUP*. Phylogenetic Analysis Using Parsimony (*and Other Methods). Version 4. Sinauer Associates. Sunderland.

Vogler, A. P., 1994. Extinction and the formation of phylogenetic lineages: Diagnosing units of conservation management in the tiger beetle Cicindela dorsalis. In: B. Schierwater, B. Streit, G. P. Wagner \& R. DeSalle (eds.). Molecular Ecology and Evolution: Approaches and Applications. Birkhauser Verlag. Basel: 261-273. 
Vogler, A. P., 1998. Extinction and the evolutionary process in endangered species: What to conserve? In: R. DeSalle \& B. Schierwater (eds.). Molecular Approaches to Ecology and Evolution. Birkhauser Verlag. Basel: 191-210.

Vogler, A. P. \& Desalle, R., 1994. Diagnosing Units of Conservation Management. Conservation Biology, 8(2): 354-363.

Vogler, A. P., Desalle, R., Assman, T., Knisley, C. B. \& Schultz, T. D., 1993. Molecular Population Genetics of the Endangered Tiger Beetle Cicindela dorsalis (Coleoptera: Cicindelidae). Annals of the Entomological Society of America, 86(2): 142-152.
Williams, B. M., 2002. Conservation Genetics, Extinction, and Taxonomic Status: a Case History of the Regal Fritillary. Conservation Biology, 16(1): 148-157.

Wyner, Y. M., Amato, G. \& Desalle, R., 1999. Captive breeding, reintroduction, and the conservation genetics of black and white ruffed lemurs, Varecia variegata variegata. Molecular Ecology, 8: S107-S115. 